\title{
New Public Management and Bureaucracy Versus Business Values and Bureaucracy
}

\author{
FRED THOMPSON \\ Willamette University \\ HUGH T. MILLER \\ Florida Atlantic University
}

\section{EDITOR'S INTRODUCTION}

Privatizing public services continues to affect the field of public personnel management. It is recently and widely reported that approximately 850,000 government jobs will be opened to private companies under new rules encouraging competition to replace federal workers who perform a variety of tasks. The rationale continues to be that many public service jobs can be done better and more cheaply by private businesses.

This provides the context for a vigorous exchange between Fred Thompson and Hugh T. Miller on the merits and legitimacy of such market-driven government reforms. Thompson claims traditional organizational arrangements are outmoded, and importing private sector models of managerial success into the public sector enhances productivity and democratic governance. Hugh Miller disagrees, rejecting the notion that the public sector has the responsibility to make itself more like business. He also questions to what extent limited government is good for democracy. Although Thompson and Miller may not have convinced each other, the reader will benefit from this elegant exchange.

-Meredith A. Newman
Special Features Editor
University of Illinois-Springfield

Review of Public Personnel Administration, Vol. 23, No. 4 December 2003 328-343

DOI: $10.1177 / 0734371 X 03257478$

(C) 2003 Sage Publications 


\title{
POINT
}

\author{
FRED THOMPSON
}

\section{WHY A NEW PUBLIC MANAGEMENT? WHY NOW?}

Paul Krugman (1998) called 1913 the high-water mark of the first global economy. He noted that during the preceding century the world economy had been transformed by technology and the widespread acceptance of the belief that free markets, with secure property rights, were the best way to achieve economic progress.

After 1913, the market atrophied, long-distance trade shrunk, private international movements of capital virtually disappeared, and one third of the world rejected private property.

How does one explain this reversal? Perhaps, more important, how does one explain the even more astonishing reversal of fortune that, at the start of the 21st century, the world has returned to more or less the same ideology of free markets, small governments, and sound money that prevailed at the beginning of the 20 th century?

The answer to the first question must be that bureaucracies replaced alternative institutional arrangements, primarily markets in the first half of the 20th century, because they outperformed them. How? Presumably, or so Alfred Chandler (1977) argued, because of technological innovations that led to massive economies of scale and/or scope.

What were the changes in technology that caused bureaucracies to outperform markets? Here, the surprising answer is changes in organizational arrangements themselves; that is, changes in organizational design, personnel systems, operational engineering, accounting systems, and control technologies. This answer reflects the current fashionable view among economists that the comparative advantage of institutional arrangements boils down to a question of information costs and that actual arrangements are solutions to information problems - the costs associated with search, bargaining, monitoring, and enforcement. Hence, transformations in organizational arrangements must be largely driven by changes in information costs. (Basic texts on information costs include Arrow, 1969; Barzel, 1982; Milgrom \& Roberts, 1992; Williamson, 1985, 1990.) 
Elsewhere, Gil Reschenthaler and I (1996) argued that changes in organizational arrangements produced four major shifts in the comparative advantage of alternative institutions in the late 19th century:

1. The efficacy of centralized allocation and ex-ante control increased relative to decentralized allocation of resources and ex-post control, which had the effect of increasing the payoff to scale.

2. The efficacy of functional structures increased relative to process-oriented structures, which had the effect of increasing the payoff to scope.

3. The efficacy of hierarchically coordinated systems increased relative to selforganizing systems, which had the effect of increasing the payoff to vertically integrated systems of command and control.

4. The relative efficacy of government provision and control increased, which had the effect of decreasing the payoffs to free markets, secure property rights, and minimal government intervention.

Of course, it is reasonable to conclude that the changes that led to mass production also promoted mass politics and that product standardization encouraged egalitarianism. Mass production required the organization of vast numbers of unskilled laborers to work assembly lines. Like circumstances imply like interests. Widespread common interests led to powerful industrial unions and many instances of popular political mobilization as well. Mass marketing and product standardization had a significant leveling effect with respect to consumption, reducing the benefits of relative wealth and, as a result perhaps, organized opposition to relatively egalitarian social policies. Consequently, from the standpoint of the argument made here and with the benefit of 20/20 hindsight, the bureaucratic (authoritarian) populism (socialism) of the first half of the 20th century now appears to be an almost irresistible consequence of industrialization (Thompson, 1998).

That said, however, if the shifts explain the rise of bureaucracy, might not recent innovations in organizational design, operational engineering, accounting systems, and control technologies, by reversing those shifts, also suffice to explain its fall?

Prussians (Heinrich von Stein, Gerhard von Scharnhorst, August von Gneisenau, and Helmuth von Moltke) perfected the bureaucratic model during the 19th century. ${ }^{1}$ Their administrative innovations included detailed centralized materials requirements and logistical planning, control by rules, standard operating procedures, the merit principle, functional administrative design, decomposition of tasks to their simplest components and narrow job descriptions, and sequential processing. 
The U.S. contribution to this system lay primarily in activity and cost measurement, and in process engineering-standardization of components, processes, and products - and in the use of electric motors to reconfigure workflow. These innovations made possible the moving, or continuous, assembly line, in which each assembler performed a single, repetitive task. The moving assembly line was first implemented at Henry Ford's Model-T plant at Highland Park, Michigan, in 1914, increasing labor productivity tenfold and permitting stunning price cuts_-from $\$ 780$ in 1910 to $\$ 360$ in 1914 . Ford made everything he needed for his cars from the raw materials on up. Of course, total vertical integration required the organization of huge numbers of activities and employees. Workers, staff specialists, and middle managers had to be recruited, sorted out, and fitted into a merit-driven hierarchical scheme; that is, bureaucracy. (For a comparative analysis of the industrial and bureaucratic revolutions see Polanyi, 1944/ 1985; Rosenberg \& Birdsall, 1986.)

Not only did bureaucracy make large, complex organizations efficient, it also made them inevitable. Only very large organizations could take full advantage of bureaucracy. Only they could afford to devote substantial amounts of resources to gathering and processing quantities of data for top management to use to coordinate activities and allocate resources (Beniger, 1986). Hence, it seemed that bigger organizations were necessarily better. In addition, there seemed to be no natural limits to this conclusion.

In the United States, the progressive movement created modern public administration. To a remarkable degree the progressive reforms - an executive, input-oriented budget; a professional civil service and merit-based public personnel administration; control by rules; standardization of procedures, task specialization, and a strict administrative hierarchy, with clearly delineated staff and line functions - were based on the Prussian model. In a few instances-the War Department under Elihu Root and the U.S. Department of Agriculture Forest Service under Gifford Pinchot, the New York City Department of Sanitation under Col. George E. Waring, for example-progressives proudly acknowledged the source of inspiration for their administrative reforms. Elsewhere, they expressed some discomfort at copying the governance institutions of an undemocratic, militaristic regime. One of the best-known apologies for this practice was Woodrow Wilson's (1887) argument that politics and administration are different functions, making it possible to borrow administrative practices from an authoritarian state without thereby threatening democratic politics: "If I see a murderous fellow sharpening a knife cleverly, I can borrow his way of 
sharpening the knife without borrowing his probable intention to commit murder with it" (p. 220).

Regardless of their source, progressive reforms led to dramatic improvements in the delivery of government services and in the productivity of public employees. Anecdotes to this effect abound: significant reductions in disease following Colonel Waring's reforms, the forest rangers' erstwhile reputation for efficiency, widespread replacement of government contracting out by in-house production, and, perhaps most telling, the early-20thcentury enthusiasm for postalization (i.e., running businesses similar to the U.S. Post Office). Not all of the evidence is anecdotal, however. Crossnational comparisons show, for example, that total factor productivity growth in surface transport once tended to be higher in nationalized systems than where government regulated price and entry, and higher in regulated systems than in competitive ones. Similar evidence exists with respect to most so-called public utilities. Empirical evidence also exists as to the consequences of the wave of reform that transformed the governments of many U.S. cities in the past century. Controlling for city and time effects, bureaucratic reform led to significantly increased rates of infrastructure investment and economic development (Rauch, 1995). Overall, by the middle of the past century, despite far higher employment growth, value added per worker remained $40 \%$ greater in the public sector than in the private.

My point is that bureaucratic arrangements once successfully provided security, jobs, and economic stability, ensured fairness and equity, and delivered the one-size-fits-all services needed during the era that lasted from the turn of the past century to the mid-1960s. In the meantime, however, the organizational arrangements invented at the dawn of the industrial era have become increasingly anachronistic.

\section{What Goes Around, Comes Around}

Centralization, executive, input-oriented budgets, standardization, and direct supervision of the flow of raw materials and components through the production process were eventually rendered obsolete by innovations in organization pioneered by General Motors under Alfred P. Sloan. The best known of these is the multiproduct, or M-form, organizational structure, in which each major operating division serves a distinct market segment, retains considerable autonomy, keeps its own books, and is evaluated using the DuPont system of financial measurement. Short-run coordination 
between GM's consumer goods divisions and the divisions making components was achieved via buyer-seller relationships_-quasi, arm's length transfer pricing arrangements. Longer run coordination was achieved via the first modern capital budgeting system used in the United States (Chandler, 1977; Womack, Jones, \& Roos, 1990). GM’s organizational innovations were widely emulated by U.S. businesses during the 1950s and 1960s.

Improvements in educational levels and advances in automation have reduced the relative efficacy of bureaucratic personnel systems: control by rules and standard operating procedures, task specialization, and sequential processing. Indeed, these have been superceded in many industries by modern, people-based human resources management (HRM) practices: selfmanaged teams, control built into job design, and decentralization of decision making as basic principles of organization, highly selective hiring of new personnel and employment security, extensive training, comparatively high compensation based on organizational performance, reduced status distinctions and barriers across levels, and extensive sharing of financial and performance information throughout the organization (Pfeffer, 1998). The consequences of these high performance HR practices include faster organizational learning and innovation, greater flexibility, skill acquisition, productivity, and ultimately improved customer service.

U.S. businesses have abandoned functional compartmentalization along with vertical integration. Arguably, these trends are being driven by reductions in communications, logistics, and information-processing costsreductions stimulated, if not caused, by the introduction of computers and by our increasing ability to use them. These reductions are breaking down economies of scale and scope built on functional specialization and vertical integration. As a result, even large companies are mimicking their smaller competitors by shrinking head offices, removing layers of bureaucracy, and concentrating on core businesses.

This has led to flatter as well as smaller organizations, organized around a set of generic value-creating processes and specific competencies. Some single-mission organizations are now organized as virtual networks, some multimission organizations as alliances of networks. Philip Evans and Thomas Wurster (1997) refer to both of these kinds of organizational arrangements as hyperarchies, after the hyperlinks of the World Wide Web. Evans and Wurster (1997) asserted that these kinds of organizations, similar to the Internet itself, the architectures of object-oriented software programming, and packet switching in telecommunications, have eliminated the need to channel information, thereby eliminating the trade-off between information bandwidth (richness) and connectivity (reach). How far 
hyperarchy will go is an open question. Evans and Wuster (1997) claimed that it will destroy all hierarchies, whether of logic or power, "with the possibility (or the threat) of random access and information symmetry" (p. 81).

These changes have already influenced business to a greater or lesser degree. They have had almost no effect on the production and delivery of public services. As a result, productivity growth in the public sector has lagged productivity growth in the private sector by a remarkable degree. Indeed, low government productivity almost wholly explains the gap between value added in manufacturing and in services. Evidently, value added per worker is only $5 \%$ lower in private services than in manufacturing, but government productivity lags manufacturing productivity by $33 \%$. The $20 \%$ of the U.S. workforce employed by government generates less than 15\% of total output (Quinn, 1992). This means that, if government workers were as productive as nongovernmental workers, GDP would be $5 \%$ higher. More dramatically, had value added per government worker increased at the same rate as in the goods sector from midcentury on, GDP would have been 13\% higher than in 2003 ( $\$ 1.4$ trillion, about three fourths of total federal, state, and local expenditures).

Moreover, we now live in an economy in which workers demand autonomy and citizens/customers demand superior service and more choice. Old-fashioned business bureaucracies cannot meet these demands; neither can old-fashioned government bureaucracies.

What the new public management calls for is the adoption of the organizational designs and practices that are transforming business: decentralized, flatter, perhaps smaller, organizations, structured around sets of generic value-creating processes and specific competencies, high-performance HRM practices, modern information technology, balanced responsibility budgeting and control systems, and loose alliances of networks (L. R. Jones \& Thompson, 1999; see also Barzelay, 1992, 2001, for the best description of this new paradigm). An example of what I am talking about is the New Zealand Post, which under its CEO, Elmar Toime, transformed itself from a typical bureaucracy to a profitable state-owned enterprise and the most efficient postal service in the world. This entailed a 30\% reduction in workforce, but because of changes in organizational design and HRM practices, "These reductions were accomplished without leaving the organization weakened by a distrustful and unmotivated workforce" (Pfeffer, 1998, p. 186).

Ultimately, we favor these things not only because we want to make the public sector more productive, but also because we want it to be more democratic. Old-style bureaucracy is authoritarian and hierarchical; those 
attributes never comported well with democratic values. Moreover, the requirements of directing giant, vertically integrated, functional organizations has tended to overwhelm the capacity of the public and its elected representatives to attend to the general welfare. Limiting the scope of the public sector to the provision of services that truly are infused with the common interest cannot but enhance the efficacy of democratic governance mechanisms.

\section{NOTE}

1. The Prussian military's role in the development of the factory system and bureaucratic organizations is described in Corvisier (1979), Dupuy (1977), A. Jones (1992), Millis (1956), and van Creveld (1977, 1985). The adoption of Prussian practices in the U.S. public sector is explicitly described in Twight (1983); see also Weinstein (1968).

\section{REFERENCES}

Arrow, K. J. (1969). The organization of economic activity: Issues pertinent to the choice of market versus nonmarket allocation. In Joint Economic Committee, 91st Congress, 1st session, vol. 1, The analysis and evaluation of public expenditures (pp. 47-64). Washington, DC: Government Printing Office.

Barzel, Y. (1982). Measurement costs and the organization of markets. Journal of Law \& Economics, 25(1), 27-48.

Barzelay, M. (1992). Breaking through bureaucracy. Berkeley: University of California Press.

Barzelay, M. (2001). The new public management. Berkeley: University of California Press.

Beniger, J. R. (1986). The control revolution: Technological and economic origins of the information society. Cambridge, MA: Harvard University Press.

Chandler, A. D. (1977). The visible hand: The managerial revolution in American business. Cambridge, MA: Belknap Press.

Corvisier, A. (1979). Armies and societies in Europe, 1492-1789 (A. T. Siddall, Trans.). Bloomington: Indiana University Press.

Dupuy, T. N. (1977). A genius for war: The German army and the general staff, 1807-1945. Englewood Cliffs, NJ: Prentice Hall.

Evans, P. B., \& Wurster, T. S. (1997, September-October). Strategy and the new economics of information. Harvard Business Review, 75, 70-82.

Jones, A. (1992). Civil War command \& strategy. New York: Free Press.

Jones, L. R., \& Thompson, F. (1999). Public management: Institutional renewal for the 21st century. Stamford, CT: JAI Press.

Milgrom, P. R., \& Roberts, J. (1992). Economics, organization, and management. Englewood Cliffs, NJ: Prentice Hall.

Millis, W. (1956). Arms and men: A study of American military history. New York: G. P. Putnam.

Pfeffer, J. (1998). The human equation: Building profits by putting people first. Boston: Harvard Business School Press. 
Polanyi, K. (1985). The great transformation. New York: Farrar \& Rinehart. (Original work published in 1944).

Quinn, J. B. (1992). Intelligent enterprise: A knowledge and service based paradigm for industry. New York: Free Press.

Rauch, J. E. (1995). Bureaucracy, infrastructure, and economic growth: Evidence from U.S. cities during the Progressive Era. American Economic Review, 85(4), 968-979.

Reschenthaler, G. B., \& Thompson, F. (1996). The information revolution and the new public management. Journal of Public Administration Research \& Theory, 6(1), 125-144.

Rosenberg, N., \& Birdsall, L. E. (1986). How the West grew rich: The economic transformation of the industrial world. New York: Basic Books.

Thompson, F. (1998). Fordism and postFordism. In P. A. O'Hara (Ed.), Encyclopedia of political economy (pp. 404-407). London: Routledge.

Twight, B. W. (1983). Organizational values and political power. University Park: Pennsylvania State University Press.

van Creveld, M. L. (1977). Supplying war: Logistics from Wallenstein to Patton. New York: Cambridge University Press.

van Creveld, M. L. (1985). Command in war. Cambridge, MA: Harvard University Press.

Weinstein, J. (1968). The corporate ideal in the liberal state: 1900-1918. Boston: Beacon.

Williamson, O. E. (1985). The economic institutions of capitalism. New York: Free Press.

Williamson, O. E. (1990). Organization theory: From Chester Barnard to the present and beyond. New York: Oxford University Press.

Wilson, W. (1887). The study of administration. Political Science Quarterly, 2(2), 197-222.

Womack, J. P., Jones, D. T., \& Roos, D. (1990). The machine that changed the world. New York: Rawson Associates. 


\title{
COUNTERPOINT
}

\author{
HUGH T. MILLER
}

\section{BUSINESS VALUES AND BUREAUCRACY}

Thompson's interpretation of organizational history and the buildup of bureaucracy convey an impressive amount of intelligence in a very short space. He is indeed the master of efficiency. His descriptions are vivid and illuminating, even though his announcement of the fall of bureaucracy is premature. His prescriptions are well intentioned, though overly imbued with business sector zeal.

Thompson writes beautifully, but what is he prescribing? Two things we already have enough of: old clichés about the superiority of business practices over public administration practices and gizmo-sounding slogans offered as management reforms. He said we need "high-performance HRM practices," along with "generic value-creating processes" and "balanced responsibility budgeting."

Thompson presents service sector productivity data as if they were established facts rather than controversial assertions. Economists openly acknowledge the trouble with measuring service sector productivity. Moreover, rapid productivity increases may be more difficult to accomplish in services than in goods. Ignoring these controversies, Thompson implies that there is a public employee problem behind the productivity data.

By drawing a circle around a bullet hole, Thompson identifies the New Zealand postal service as a bulls-eye, an exemplar of what the remaining hundreds of thousands of public sector organizations could do if they would just transform themselves into "decentralized, flatter, perhaps smaller, organizations, organized around sets of generic value-creating processes and specific competencies, high-performance HRM practices, modern information technology, balanced responsibility budgeting and control systems, and loose alliances of networks."

The predictable upshot of Thompson's article is his claim that productivity growth in government is less than productivity growth in the private sector, and, moreover, it is up to the public sector to remake itself in the image of business. Never mind that fourth-quarter 2002 productivity improvement (the most recent available at this writing) in the U.S. nonfarm 
business sector showed a productivity decline of $0.02 \%$. (And yet no one views this as an employee issue.)

Two things are ignored amid the praise for whiz-bang new organizational designs that have supposedly displaced old-time bureaucracy in the private sector but not in the public sector: (a) the displacement of old-time bureaucracy with new forms has not occurred in the private sector, and (b) there have been tremendous changes in service delivery instruments that have taken place in the public sector, including contracting out, policy networks, interagency task forces, and special district governments.

\section{Bureaucracy as Rhetorical Foil}

The term bureaucracy is easily invoked as a pejorative description for "old" or inefficient organizations. However, the reports of its demise are premature. On one hand, bureaucracy is not as totalizing as Thompson makes it out to be. Henry Ford's company never did, in fact, make "everything he needed for his cars from the raw materials on up." The "total vertical integration" that bureaucracy supposedly achieved is a chimera. Despite Ford's efforts to totalize, high demand for some models necessitated contracting out for certain parts and assemblies. On the other hand, the reforms that Thompson offers are an extension of the same instrumental rationality that also sustains bureaucracy. Precision, speed, clarity in communication, reduction of friction, reduction of personnel costs- these are the technical advantages of bureaucracy, according to Max Weber. It is no coincidence that Thompson's management reforms are intended to achieve these same sorts of effects.

Meanwhile, the characteristics that make bureaucracy what it is remain intact: "The principles of office hierarchy," "levels of graded authority," and "a firmly ordered system of super- and subordination" (Weber, 1946, p. 197). The suppositions of expert training remain. Duties of the job continue to demand the full working capacity of the employee. General office rules, to this day, must be learned and followed.

Moving beyond bureaucracy in a serious way involves a critical assessment of the instrumental rationality that informs modern organizations of all kinds. Max Weber (1946) said that the decisive reason for the advance of bureaucratic organization "has always been its technical superiority over any other form of organization" (p. 214). It is worth remembering the source of such advance: 
Today, it is primarily the capitalist market economy which demands that the official business of the administration be discharged precisely, unambiguously, continuously, and with as much speed as possible. Normally, the very large modern capitalist enterprises are themselves unequalled models of strict bureaucratic organization. Business management throughout rests on increasing precision, steadiness, and, above all, the speed of operations. (Weber, 1946, p. 215)

The ethic of instrumental rationality that capitalism and bureaucracy have brought about is now so thoroughgoing that bureaucracy - the primary vehicle for spreading instrumental rationality into the culture-is ridiculed for no longer being efficient enough. Yet bureaucracy has set the terms, and the game is still being played according to the rules of bureaucratic rationality. Efficiency and rapid, unambiguous communication remain the foremost criteria that are used to assess the "technical superiority" of organizational form. Hence the "fall" of bureaucracy in the corporate sector is surely an overstatement. Instead, performance management, outcome measurement, and results-oriented managerialism are tributes to the triumph of bureaucracy's core value, instrumental rationality.

\section{Democratic Innovations}

Thompson wants public sector bureaucracies to operate more like a business and thinks that democratic values run in precisely the same direction. We can agree that democratic structural innovations that increase information flow (bottom up as well as top down) should be developed in the public sector - and, indeed, this is happening in a vibrant way. However, Thompson ignores the rapidly expanding body of research on policy networks, decentered governance, and deliberative policy implementation in Denmark, the United Kingdom, the United States, and the Netherlands. Public administration theorists concerned about democratic governance watch these experiments and innovations closely.

Amid increasing specialization (which began as a bureaucratic phenomenon), it seems as though the literature on organizational efficiency and on democratic policy implementation exist in separate spheres of specialization.

Even when management reforms can be justified on efficiency grounds, it would be claiming too much to assert that one has, thereby, justified the reforms on democratic grounds as well. Can efficiency and democracy be discussed on the same page? Some say yes. As Thompson puts it, "Ulti- 
mately, we favor these things not only because we want to make the public sector more productive, but also because we want it to be more democratic."

However, when the discussion shifts from efficiency to democracy, the politics are exposed. Conservative ideology equates democracy with limited government, rather than with expanded participation in it. Thompson said, "Limiting the scope of the public sector to the provision of services that truly are infused with the common interest cannot but enhance the efficacy of democratic governance mechanisms." One begins to suspect that, by the end of the article, Thompson's critique of public sector productivity, on the supposed politically neutral terrain of efficiency, has transformed itself into an article on limited government. An economic definition of democracy, similar to the others, has its upside and its downside.

\section{The Business Ethic}

Thompson ignores the downside of the business ethic, dubbed "infectious greed" by Alan Greenspan. Avarice would also be a good term to use. In the wake of the scandals at Global Crossing, Adelphia, Enron, Arthur Andersen, WorldCom, and so on, it takes chutzpah to hold the business model up as one worth emulating in the public sector. Instead, the indulgent and dangerously righteous business model generates a public sector ethics that should give one pause.

Consider this example from my home area in South Florida. The Pembroke Pines City Manager Charles F. Dodge and his assistant Martin J. Gayeski were paid $\$ 306,000$ per year between them, and they now will be entitled to pension benefits because they are retiring. This story (from Miami Herald reporter Scott Andron) would be ho-hum news, except for one catch.

Now Dodge and his subordinate will be paid $\$ 3,345,000$ over 5 yearsas consultants for Charles F. Dodge LLC, the brand-new consulting firm that just won a noncompetitive contract to manage the city (Andron, 2003). I wonder if this is the sort of high-performance HRM practice that Thompson has in mind.

There are several features of the deal worth considering:

1. The city will now pay $\$ 363,000$ per year additional for city management services. Before the last city council meeting, the city was paying $\$ 306,000$ per year total. The new total cost is $\$ 669,000$ per year, more than double.

2. The former city manager Dodge (now consultant Dodge) will begin immediately to collect pension benefits (of unknown amount). 
3. There was no competitive bidding process. The city's attorney said there was no need for it.

According to city council members, Dodge and Gayeski were doing an outstanding job managing the city. Dodge justified his contract amount by touting several personnel inactions. He saved the city money by not hiring an education director to oversee the city's charter schools; by not hiring a project manger to oversee development of a park; by not hiring an additional assistant city manager. The city council was persuaded by this argument, and I would not be surprised if advocates of "new public management" would likewise be persuaded.

What is my objection? In a culture dominated by corporate practices and business ethics, limited government has slightly different connotations than it did for the U.S. founders when the business corporation had no legal status. Unlike classic, liberal political theory that extolled civil society and the autonomous individual, Thompson extols corporate practices.

Thompson's reforms are presented as good for democracy. They might save taxpayers money, and they might make governmental organizations more effective. These would be good things. However, are they democratic in any robust sense of the term? I doubt it. Something more profound is happening, instead. The instrumentally rational predisposition, honed and improved though corporate practices, stands ready to colonize culture and its politics.

\section{REFERENCES}

Andron, S. (2003, February 11). Dodge's company to run Pines. Miami Herald-Broward, p. $1 \mathrm{~B}$.

Weber, M. (1946). Bureaucracy. In H. H. Gerth \& C. W. Mills (Eds. \& Trans.), From Max Weber: Essays in sociology (pp. 196-252). New York: Oxford University Press. 


\title{
RESPONSE TO HUGH T. MILLER
}

\author{
FRED THOMPSON
}

ORDINARY DEMOCRACY AND THE NEW PUBLIC MANAGEMENT

Government does not have an employee problem; it has a publicmanagement policy problem. According to the Volker Commission (National Commission on the Public Service, 2003),

The federal government is not performing nearly as well as it can or should. The difficulties federal workers encounter in just getting their jobs done has led to discouragement and low morale. (p. iv)

A clear sense of policy direction and clarity of mission is too often lacking, undercutting efficiency and public confidence. As a result, there is real danger of healthy public skepticism giving way to corrosive cynicism. (p. iv)

To me, democracy means self-determination - the power to influence decisions that are central to one's life. It is true: I like the idea of limited government. I also confess to being a managerialist and an instrumental rationalist (Is there any other kind?). Government works best where participation in public policy making is widespread. Unfortunately, because people treat participation in decision making as a cost and because they do not see government as central to their lives, many opt out. One does not have to be a right-winger to believe that government performance might be improved or that the citizenry's abilities to control its elected agents might be enhanced if their attentions and responsibilities were suitably focused on fundamental issues.

More important, work is central to our lives. However, at work, we are often silenced. "The principles of office hierarchy," "levels of graded authority," and "a firmly ordered system of super- and subordination" are inimical to democracy. They are also increasingly inimical to high performance. Nowadays, high-performing entities are more likely to be designed around team-based collaborations that successfully spread authority and responsibility throughout the organization, and thereby mobilize the collective intelligence of their members.

IBM's Dallas, Texas, facility is an example. It mimics a market. Everyone is either a customer or provider, depending on the transaction, thereby transforming the facility into a network of exchanges. Each exchange is a 
closed loop involving four steps: request from a customer, offer from a provider, negotiation of the task to be performed, and definition of success, performance, and customer acceptance. Until the last step is completed, the task is unfinished. IBM uses powerful computers to track these loops and monitor the progress of each transaction. The result has been to empower workers, eliminate boundaries and bottlenecks, and boost productivity through the ceiling.

As Hugh Miller notes, some government organizations (e.g., Oregon's housing authority under the leadership of Rey Ramsey [Hecht \& Ramsey, 2001]) have copied well-managed businesses by organizing themselves into similar alliances of networks, sharing their top management, core competencies, and a common culture, using computers to chart activities and operational flows. Their control systems are like those of centralized bureaucracies in that they collect a lot of real-time information on operations. Unlike the control systems of stovepiped, centralized bureaucracies, however, which passed the exercise of judgment up the managerial ranks, this information is used to push it down into the organization to wherever it is most needed - at delivery, in production, or to the client.

Anyone committed to democratic governance should be truly excited by these innovations.

\section{REFERENCES}

Hecht, B. L., \& Ramsey, R. (2001). ManagingNonprofits.org: Dynamic management for the digital age. New York: John Wiley.

National Commission on the Public Service (Volcker Commission). (2003). Urgent business for America: Revitalizing the federal government for the 21st century. Retrieved June 3, 2003, from www.brookings.edu/dybdocroot/gs/cps/volcker/reportfinal.pdf

FRED THOMPSON is Grace and Elmer Goudy Professor of Public Management \& Policy, Atkinson Graduate School of Management, Willamette University. He edits the International Public Management Journal and is a CARR fellow, London School of Economics.

HUGH T. MILLER is professor and director of the School of Public Administration at Florida Atlantic University. He is the author of Postmodern Public Policy. 